Journal of Primary Education
$9(3)(2020): 278-285$
UNNES
https://journal.unnes.ac.id/sju/index.php/jpe

\title{
The Effectiveness Analysis of Discovery Learning Assisted by Interactive Video toward Social Study Critical Thinking Skills of Primary School
}

Hilda Dhaniartika Nurma'ardi ${ }^{1 凶}$, Rusdarti Rusdarti $^{2}$, Murwatiningsih Murwatiningsih $^{2}$

DOI: https://doi.org/10.15294/jpe.v9i3.37935

${ }^{1}$ Universitas Sultan Ageng Tirtayasa, Indonesia

${ }^{2}$ Pascasarjana, Universitas Negeri Semarang, Indonesia

\begin{tabular}{l} 
Article Info \\
\hline History Articles \\
Received: \\
25 February 2020 \\
Accepted: \\
25 March 2020 \\
Published: \\
31 May 2020 \\
\hline Keywords: \\
Critical Thinking Skill, \\
Discovery Learning, \\
Interactive Video.
\end{tabular}

\begin{abstract}
Critical thinking skills must be owned by primary school students to face the $21^{\text {st }}$-century learning era. It can be trained in schools by implementing a discovery learning model in learning processes. This research aims to analyze and find out how discovery learning effectiveness assisted by interactive video toward critical thinking skills of Social study for fourth graders. The research methodology was quasi-experimental research while the technique of sampling was purposive sampling. In this research, Public Primary School 02 Pringapus functions as control group which was intervened by discovery learning and Public Primary School 01 Pringapus functions as experimental group which was intervened by discovery learning assisted by interactive video. The techniques of collecting data were critical thinking skill question, questionnaire, interview, and documentation. The results of classical accomplishment showed that the result of control group was $54.84 \%$ with average score 70 . Meanwhile, the experimental group obtained $96.67 \%$, with average score 76.67 . The results of n-gain score of control group was 0.34 while the experimental group was 0.42 . Both of them were categorizeed moderate. The findings showed that discovery learning implementation assisted by interactive video was effective in improving social study critical thinking skills of primary school students. This research is expected to be basis of developing and improving social study critical thinking skills for primary school students.
\end{abstract}




\section{INTRODUCTION}

Current fast growing era development is a supportive factor which makes educational world gets more competitive in strengthening educational quality to create the next generations which could compete in the future. Maduretno, Sarwanto, and Sunarno (2016) states that, generally, education field in Indonesia is in the lowest rank. Therefore, to prepare educated generations needs efforts to realize the fostered dreams for the sake of better Indonesia education. So, in $21^{\text {st }}$ century, every teacher is required to be able to meet all students' needs in mastering various skill aspects, such as creativity, critical thinking skill, collaborating skills, and communication.

One of the skills which must have specific attention is critical thinking skill. It is in line with argument stated by Sulistiani and Masrukan (2016) who emphasizes that critical thinking skill is a skill needed in current era. It is since student skill in thinking critically needs many long-term benefits and could regulate students' skills in learning which can empower themselves individually to contribute creatively toward the chosen options.

Critical thinking skill requires students to analyze, interpret, and provide an alternative solution in solving the faced problems (Kurnianto, et al. 2020). However, surely in the efforts to improve students' critical thinking skills, it cannot just be promoted simply. It must be motivated by various supportive aspects. If it is seen from the inner side of learning process, the aspects may take forms as varieties in learning. There are several ways to use, such as by using model, method, strategy, or learning media in learning process which should be adjusted first with the presented material.

Teacher's skill in using learning varieties really plays important roles in learning process. It is due to a teacher holds strong control to direct how the learning will be carried out so learning will be more impressive and easy to understand. Not only become an important matter to do, but learning variety appropriate to learning process also can be used as a trigger to train students' skills in processing information and considering decision when they are faced by problems. Thus, students could learn materials based on what has become the collective purpose in learning.

It cannot be denied that teachers must feel challenged to struggle in using a lot of varieties in learning which should be adjusted to the taught material. This is in line with UribeEnciso, Enciso and Daza (2017) stating that it has been the time for teachers to play important roles in changing an educational paradigm to assist students in developing critical thinking skill. Based on those considerations, teachers should have been able to create varieties in learning to create meaningful learning. Thus, students' critical thinking skill will develop better.

However, although it has been considered important, learning varieties are not carried optimally. Even though, Syah (2017) stated that excellent learning ways would contribute greatly to learning process because students are supported in learning. Novita Sari and Murwatiningsih (2015) also stated that learning model is a description of learning process flows done as efforts to reach certain objectives. The ways which could be done by using learning varieties may take forms into model and video to use by teachers in improving critical thinking skills.

One of applicable learning media to use as effort in improving critical thinking skill is discovery learning.It is in line with Nafisa and Wardoyo (2019) that the use of appropriate learning model, as for example the use of discovery learning, is effective in improving critical thinking skills. Kurniasih and Sani (2014) stated that discovery learning is a learning process done by finding a notion of information result or data series which are obtained through observation or experiment. With another word, it could be concluded that discovery learning requires students to find or investigate what they learn. So, they could understand better and memorize easier what they have learned. Through critical thinking skill, students would be easier to understand a concept and have 
better sensitivity toward their faced problems (Fembriani, Khumedi, and Anni, 2015).

Finding information by students themselves as required in discovery learning would make students able to process and transform their unknown knowledge to the known knowledge. Thus, students would obtain evidence or answer of the question or problems appropriately (Rahayu, Mawardi and Astuti, 2019) stated that discovery learning could improve critical thinking skills in learning. Students could find what has not been known for them while teachers only act as facilitators whom make students more active in learning. Utami (2017) also studied discovery learning and stated that the learning could improve social study critical thinking skill of JHS students. Based on the argument, then it could be concluded that the implementation of discovery learning toward critical thinking skill had influential correlation and could strength students' skills in learning.

Consideration of using discovery learning in improving critical thinking skill could be integrated by using interactive video learning media, such as interactive video. The use of interactive video in learning could be an alternative to make students more focus, interested, and make them transforming the known and unknown knowledge about a learned lesson. It is also strengthened by $\mathrm{He}$, Craig, and Wen (2013) who stating that critical thinking skill of students could be internalized by focusing on roles and technologies.

Sari and Setiawan (2018) stated that the use of learning media could be a mode of information from the senders to the receivers. So, what is going to be delivered by senders could be properly received. Interactive learning video could be used as learning media in the form of video which has a material to be delivered by the senders to the receivers. That media could be integrated to discovery learning model because the contents of interactive video are presented alongside with the lesson material. It will make students' critical thinking skill transformed broader. Besides, students could also be focused in constructing critical thinking which would make them finding and drawing the points of what they learn.

The use of discovery learning assisted by interactive video could improve critical thinking skill of students since students will conduct more various, joyful, and challenging learning to create their thinking patterns developed in facing the obtained information. Discovery learning assisted by interactive video could be an appropriate alternative because interactive video learning has interesting contents. The media could also improve new perceptions and consideration in receiving the presented information in the material contained in it. Learning media could be used as media for students to conduct investigation along with discovery learning. It is a series of argumentation between the known and unknown knowledge.

The use of discovery learning model assisted by interactive video is really appropriate to be implemented at fourth grade of Primary School. It is due to the student age at fourth grade is a period in which students could understand learning material concretely. The use of interactive video indirectly influences students' understanding because they could see directly although it is just from a video. Thus, it makes students being able to have better actual learning experience.

Therefore, the purpose of this research is to analyze effectiveness of discovery learning assisted by interactive video toward primary school students critical thinking skills. This research is expected to be developmental foundation in improving Primary School students' social critical thinking skills.

\section{METHODS}

This research used quantitative research with quasi experimental design. The design consists of two subjects groups intervened by two different treatments. The population in this research consisted of all fourth graders of Gatot Subroto cluster.

The reason to take the fourth graders as the population was due to transition period of 
lower class to higher class in which requires students to try analyzing what they learn by assistance of media to improve their critical thinking skills.

The sample of this research was taken by purposive sampling technique. It is a sampling technique by using certain considerations. The results were fourth graders of Public Primary School 2 Pringapus were as control group and fourth graders of Public Primary School 1 Pringapus was as experimental group. The considerations were done because both schools had equal value characteristics, critical thinking skills, and school accreditations.

Techniques of collecting data were test and non-test. The research finding data was analyzed by requirement test, consisting of normality and homogeneity tests. Besides that, this research also used classical completences test, sample average t-test, and n-gain test.

The classical accomplishment test was done to find out the percentage of students' accomplishment. T-test was used to find out class average variance of both groups. N-gain test was used to find out students' learning outcome improvements. Those tests were done to analyze effectiveness of discovery learning implementation assisted by interactive video toward students' critical thinking skills.

\section{RESULTS AND DISCUSSION}

The success in learning is due to its learning process. The students seemed active and interested in following the learning. They were able to solve the presented problems critically by using discovery learning. It is supported by Agustina, Achmad \& Yolida (2015) whom stated that discovery learning could influence to improve students' critical thinking skills.

The use of discovery learning actively could make students involved in learning. It would make them investigate by themselves about their obtained problems so that the results from the obtained knowledge could last longer in their memories. Besides, Patandung (2017) and Mahartati (2017) stated that the use of discovery learning was effective to improve students' learning motivations. High motivation would influence students' skills. It is due to they would be triggered to active in learning process. (Asrul, Ridlo, and Susilo, 2018).

In learning process, the implementation of discovery learning was integrated to interactive video media uses to make students interested in following a learning process. Thus, students would more focus and their criticism would be optimal. Bagja and Yuliana (2019) stated that the use of media and appropriate method in learning would make learning more meaningful and make teacher's skill in managing the class more optimal.

Pratama, Nuryatin, and Mardikantoro (2017) stated that the strength of using learning media is due to the existence of interesting display by combining colors and sounds which are expected to create joyful learning situation.

In the first stage, students were faced at something causing confusion through interactive video presentation during discovery learning. Then, the teacher continued it by giving no generalization. It was done to keep the students' curiosities which would lead them to investigate it by themselves. This stimulus was started by asking questions and showing video to students.

By giving video, students would be elicited to think and ask based ont he pictures about the presented matter in the video. Discovery learning assisted by interactive video effectively could be used in improving Social study critical thinking skill of the students. The improvement was observed regularly by using observation sheet.

The syntaxes of discovery learning assisted by interactive video are presented in Figure 1-6.

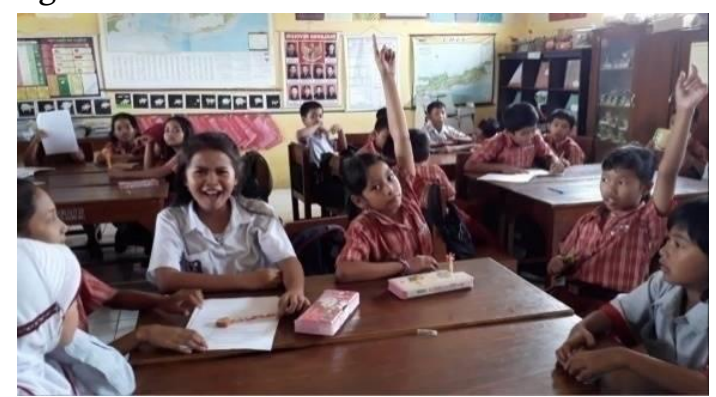

Figure 1. Stimulating 
On the first phase as in Figure 1, the stimulation, the students were given questions and a video was presented to elicit their thoughts and to start asking questions based on the explanation in the video.

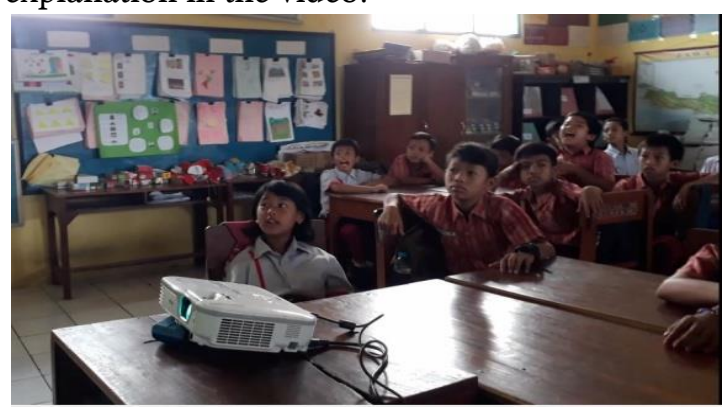

Figure 2. (Questions)

Second phase as in Figure 2, problem statement, students were grouped and asked to observe the video. They were elicited to ask question in identifying the explanation of the second video by using job types on in accordance to surrounding situation.

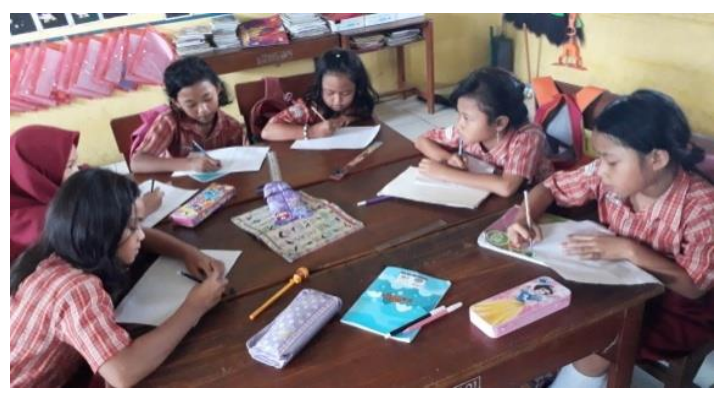

Figure 3. Data Collection

Third phase as in Figure 3, data collection, the students were asked to collect information so they were prepared to answer the questions in doing or expressing the information as answers in the provided LKDP sheet.

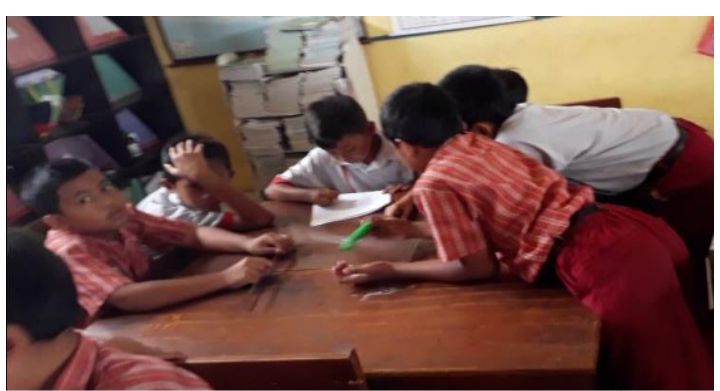

Figure 4. Data processing

Fourth as in Figure 4, data processing, in this phase, students were let to develop their obtained information as conceptual construction and generalization so they could find their own knowledge from the alternative answers which required logic proof based on various obtained sources.

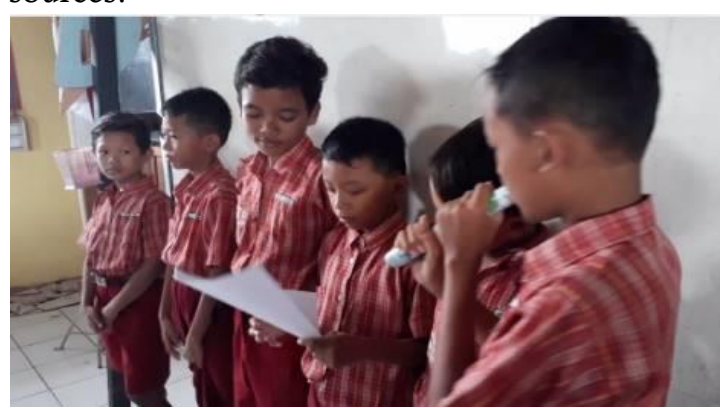

Figure 5. Verification

The fifth phase as in Figure 5, verification, after the data was collected and processed, the students were asked to present the report results to find out suggestions and rebuttals from each group or student. Thus, the previous data could be used as problem formulation in the form of hypothesis and could be verified.

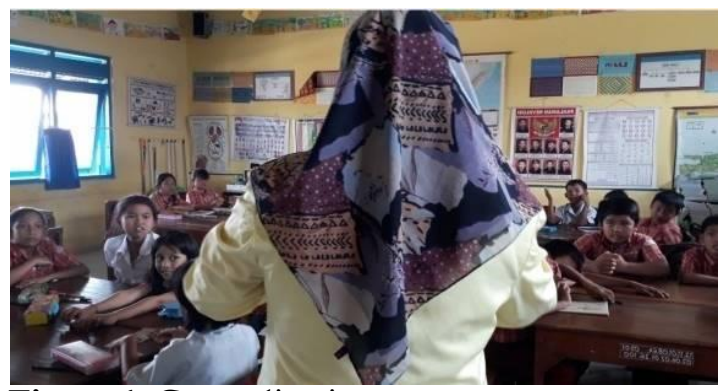

Figure 6. Generalization

The sixth phase as in Figure 6, generalization, after all groups made conclusion, they were given conclusion with the teachers to verify the data. Thus, the collected data and hypothesized problem formulation could be verified in term of its relevance. The plots of the phases belong to discovery learning.

\section{Requirement Test of Students' Critical Thinking Skills \\ Tests of Normality}

The test was used to find out whether the data is normally distributed or not. The proposed hypothesis is Ho = normally distributed; $\mathrm{H} 1=$ not normally distributed. The criteria of the test is Ho is accepted if Sig $>0.05$. 
The normality test of both groups could be seen in Table 1.

Table 1. Data of Normality Test

\begin{tabular}{llll}
\hline & \multicolumn{3}{l}{ Kolmogorof-Smirnov } \\
\cline { 2 - 4 } & Statistics & F & Sig. \\
Control Group & 1.040 & 31 & 0.230 \\
Experimental & 1.170 & 30 & 0.129 \\
Group & & & \\
\hline
\end{tabular}

Normality data test was used to find out whether the posttest scores of both groups were normally distributed or not. The test was done by using Kolmogrov - Smirnov. The results of normality test on Table 1 could be concluded that the data is normally distributed.

\section{Homogeneity Test}

This test was done to find out the property of the data whether it is homogeneous or not by comparing the F-test significant scores which are stated in significant level table, 0.05 . If the significance of $\mathrm{F} \leq 0.05$, it could be concluded that the data is not homogeneous. The homogeneity test in this research shows score 5.053 with df1 1 and df2 59, sig score 0.028. Based on the explanations, it could be concluded that the scores of the students on Social study, both control and experimental group, were not homogeneous.

\section{Hypothesis Tests}

\section{Average Comparison Test}

This test was used to find out differences of both groups dealing with students' critical thinking skills. Based on the test, the differences were obtained by sig score $=0.000<0.05$ with $\mathrm{t}$ count $=3.734>2.004=\mathrm{t}$ table. Thus, $\mathrm{H}_{\mathrm{a}}$ is accepted. With another word, the students' critical thinking skills taught by discovery learning assisted by interactive video were better than those taught by only discovery learning.

\section{Classical Accomplishment Test}

This test was done to find out the accomplishment of each individual classically dealing with their critical thinking skills found in both groups.
The results of classical accomplishment is presented in Table 2.

Tabel 2. Classical Accomplishment Test

\begin{tabular}{lcccccc}
$\begin{array}{l}\text { Classical } \\
\begin{array}{l}\text { Accomplish } \\
\text { ment Test }\end{array}\end{array}$ & $\mathbf{N}$ & $\begin{array}{c}\text { Min } \\
\text { Score }\end{array}$ & $\begin{array}{c}\text { Max } \\
\text { Score }\end{array}$ & Mean & SD & P (\%) \\
\hline Control & \multirow{2}{*}{31} & 45 & 75 & 54.68 & 9.48 & 12.90 \\
& 55 & 85 & 70.00 & 7.95 & 54.84 \\
& & 45 & 75 & 60.00 & 9.00 & 20.00 \\
$\begin{array}{l}\text { Experimen- } \\
\text { tal }\end{array}$ & 30 & 65 & 90 & 76.66 & 5.77 & 96.67 \\
\hline
\end{tabular}

Based on Table 2, it could be concluded that classical accomplishment test result of experimental group reached the classical accomplishment more optimally than the control group.

\section{N-gain Test of Critical Thinking Skills}

The $\mathrm{N}$-gain results of control group was 0.34 , categorized moderate. Meanwhile, the experimental group obtained 0.42 , categorized moderate. It could be concluded that the highest improvement was found in experimental group.

Based on the data, discovery learning model assisted by interactive video on experimental group was effective to improve critical thinking skill than control group. Besides that, it is supported by Putri, Mulyanti, and Imswatama (2018) that the use of discovery learning was effective to improve critical thinking skills and motivate students learning the presented materials. It is supported by Martanti and Rusdarti (2019) stating that appropriate learning media selection could be an important matter to ensure the wanted information delivered and understood by students. Thus, students could optimally think critically.

\section{Learning Motivation}

Based on the findings, it could be concluded that discovery learning assisted by interactive video was effective to improve students' critical thinking skills. The findings are also supported by student learning motivation questionnaire result as seen in figure 7 . 


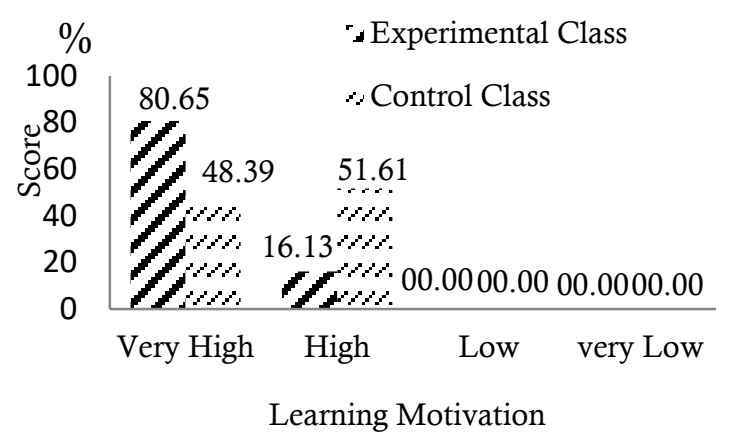

Figure 7. Experimental and Control Group Learning Motivation

The use of discovery learning assisted by interactive video made students more enthusiastic in learning what was being taught by the teacher. The learning display was brought interestingly in the form of interactive videos and discovery learning process sequence. It made students active, interested, and challenged to keep more focus with the learning. It was proven by questionnaire results given to both experimental and control group students.

Therefore, based on Figure 7, it could be concluded that students' learning motivation achievement results of experimental group was higher than control group. It means discovery learning assisted by interactive video is effective to improve students' critical thinking skills since it motivates students to learn more optimally than control group.

\section{CONCLUSION}

Based on the findings, it could be found differences of students' critical thinking skills taught by discovery learning assisted by interactive video to those taught by only discovery learning. Discovery learning assisted by interactive video was effective to improve critical thinking skill and it was found to reach better classical accomplishment on experimental group than control group. The $\mathrm{N}$-gain calculation of control group students, taught by using only discovery learning, resulted to moderate category. These findings are supported by questionnaire results stating that optimization of students' learning motivations of experimental group was better than control group.

\section{REFERENCES}

Agustina, M., Achmad, A., \& Yolida, B. (2015). Pengaruh Model Discovery Learning Terhadap Kemampuan Berpikir Kritis dan Hasil Belajar Siswa. Jurnal Bioterdidik, Wahana Ekspresi Ilmiah, 3(6), 1-10.

Asrul, A., Ridlo, S., \& Susilo, S. (2018). Creative Thinking Analysis, Motivation and Concept Mastery on Learning of Cooperative Discovery Model in Elementary School. Journal of Primary Education, 7(1), 48-56.

Uribe-Enciso, O. L., Enciso, D. S. U., \& Daza, M. D. P. V. (2017). Critical Thinking and its Importance in Education: Some Reflections. Rastros Rostros, 19(34), 78-88.

Fembriani, Khumedi, \& Anni, C. T. (2015). Pengembangan Perangkat Pembelajaran IPA Model Learning Cycle 7E untuk Meningkatkan Kemampuan Berpikir Kritis. Journal of Primary Education. 4(1), 15-23.

He, H., Craig, R., \& Wen, J. (2013). Developing Critical Thinking Skills and Effective CoOperative International Accounting Degree Programs in China. Asian Review of Accounting, 21(2), 144-159.

Kurnianto, B., Wiyanto, W., \& Haryani, S. (2019). Critical Thinking Skills and Learning Outcomes by Improving Motivation in the Model of Flipped Classroom. Journal of Primary Education, 9(3), 282-291.

Kurniasih, I., \& Berlin, S. (2014). Perancangan Pembelajaran Prosedur Pembuatan RPP yang Sesuai dengan Kurikulum 2013. Jakarta: Kata Pena.

Maduretno, T. W., Sarwanto, S., \& Sunarno, S. (2016). Pembelajaran IPA dengan Pendekatan Saintifik Menggunakan Model Learning Cycle dan Discovery Learning ditinjau dari Aktivitas dan Motivasi Belajar Siswa terhadap Prestasi Belajar. Jurnal Pendidikan Fisika dan Keilmuan (JPFK). 2(1), 1-11.

Mahartati, I. G. (2017). Meningkatkan Motivasi dan Hasil Belajar Tematik Peserta Didik dengan Mengoptimalkan Penerapan Model Discovery Learning di SD Negeri 3 cakranegara. Jurnal Kependidikan: Jurnal Hasil Penelitian dan Kajian Kepustakaan di Bidang Pendidikan, Pengajaran dan Pembelajaran, 3(2), 245-250. 
Martanti, W. W., \& Rusdarti, R. (2019). Keefektifan Metode Pembelajaran Student Team Achivment Divison (STAD) berbantuan Media Android. Economic Education Analysis Journal, 8(3), 1216-1123.

Nafisa, D., \& Wardono, W. (2019). Model Pembelajaran Discovery Learning berbantuan Multimedia untuk Meningkatkan Kemampuan Berpikir Kritis Siswa. PRISMA, Prosiding Seminar Nasional Matematika, 2, 854861.

Patandung, Y. (2017). Pengaruh Model Discovery Learning terhadap Peningkatan Motivasi Belajar IPA Siswa. Journal of Educational Science and Technology (EST), 3(1), 9-17.

Pratama, G. S., Nuryatin, A., \& Mardikantoro, H. B. (2017). Pengembangan Perangkat Pembelajaran Menulis Deskriptif dengan Pendekatan Savi Berbantuan Video bagi Siswa SD. Journal of Primary Education, 6(1), 71-80.

Putri, E. A., Mulyanti, Y., \& Imswatama, A. (2018). Pengaruh Pembelajaran Discovery Learning terhadap Kemampuan Berpikir Kritis Peserta Didik ditinjau dari Motivasi Belajar. Jurnal Tadris Matematika. 1(2), 167-174.

Rahayu, R. D. Y., Mawardi, M., \& Astuti, S. (2019). Peningkatan Keterampilan Berpikir Kritis dan
Hasil Belajar Siswa Kelas 4 SD melalui Model Pembelajaran Discovery Learning. (JPDI) Jurnal Pendidikan Dasar Indonesia, 4(1), 8-13.

Sari, A. P., \& Setiawan, A. (2018). The Development of Internet-Based Economic Learning Media Using Moodle Approach. International Journal of Active Learning, 3(2), 100-109.

Sari, N., \& Murwatiningsih, M. (2015). Penggunaan Model Inquiry Learning untuk Meningkatkan Hasil Belajar Siswa. Economic Education Analysis Journal, 4(1), 151-163.

Sulistiani, E,. \& Masrukan, M. (2016). Pentingnya Berpikir Kritis dalam Pembelajaran Matematika untuk Menghadapi Tantangan MEA. Seminar Nasional Matematika $X$ Universitas Negeri Semarang 2016. 1(1), 605612.

Syah, M. (2017). Psikologi Pendidikan Dengan Pendekatan Terbaru. Bandung: PT Remaja Rosdakarya.

Utami, M. F. L. B. (2017). Penerapan Strategi Discovery Learning (DL) untuk Meningkatkan Keterampilan Berpikir Kritis dan Pemahaman Konsep IPA. JINoP (Jurnal Inovasi Pembelajaran), 3(1), 483-490. 